\title{
First molecular characterization of Galba neotropica in Uruguay
}

\author{
Armúa-Fernández $\mathrm{MT}^{1^{*}}$, Castro $\mathrm{O}^{2}$, Correa $\mathrm{O}^{2}$, Carvalho $\mathrm{L}^{1}$, Mangold $\mathrm{A}^{3}$, Sanchís $\mathrm{J}^{4}$, Venzal $\mathrm{JM}^{1}$ \\ 1 Laboratorio de Vectores y enfermedades transmitidas, Facultad de Veterinaria, CENUR Litoral Norte - Salto, \\ Universidad de la República, Salto, Uruguay \\ 2 Departamento de Parasitología Veterinaria, Facultad de Veterinaria, Universidad de la República, Montevideo, \\ Uruguay \\ 3 Estación Experimental Agropecuaria INTA Rafaela, Santa Fe, Argentina \\ 4 Facultad de Veterinaria, CENUR Litoral Norte - Salto, Universidad de la República, Salto, Uruguay
}

* Correspondence: María Teresa Armúa-Fernández, Laboratorio de Vectores y enfermedades transmitidas, Facultad de Veterinaria, CENUR Litoral Norte - Salto, Universidad de la República, Rivera 1350, 50000, Salto, Uruguay E-mail: m.teresa.armua@gmail.com

Received: 24 August 2016. Accepted: 28 September 2016. Available online: 29 September 2016 Editor: P. Beldomenico

SUMMARY. Until recently, it was believed that only two lymnaeid species (i.e. Galba viatrix and Pseudosuccinea columella) occurred in Uruguay. However, based on a molecular approach, an additional species Galba cubensis, was recently discovered. The aim of this study was to molecularly characterize different lymnaeid populations from the northern region of Uruguay. The lymnaeids collections were carried out in two farms of the departments of Paysandú and Tacuarembó. The collected lymnaeids were divided in two fractions, one fraction was used for conchological analyses and detection of trematode larval stages, while the other fraction was used for molecular studies. Three PCRs targeting the 16S, ITS-2 and COI DNA regions were performed and the amplicons obtained were direct sequenced. The sequences were used for homology search and construction of phylogenetic trees by the maximum-likelihood method. The sequencing results revealed that both isolates corresponded to Galba neotropica. The phylogenetic analyses placed our isolates among the $G$. neotropica monophyletic group, closely related to other isolates of this species found in several South American countries. To our knowledge, this is the first record of $G$. neotropica in Uruguay and the confirmation as competent intermediate host of Fasciola hepatica. Further studies are needed to define the distribution and the role of each lymnaeid species in the transmission of F. hepatica in Uruguay.

RESUMEN. Primera caracterización molecular de Galba neotropica en Uruguay. Tradicionalmente se indicaba que existían dos especies de limneidos en Uruguay: Galba viatrix y Pseudosuccinea columella. Sin embargo, en los últimos años se identificó por medio de técnicas moleculares una tercera especie, Galba cubensis. El objetivo de los autores fue muestrear e identificar por medios moleculares poblaciones de limneidos del norte del país. Las colectas fueron realizadas en establecimientos rurales de los departamentos de Tacuarembó y Paysandú. Los caracoles colectados fueron divididos en dos fracciones, una de ellas fue destinada para el estudio morfológico de las conchillas y búsqueda de larvas de trematodos. La otra fracción se usó para la caracterización molecular. Tres genes fueron amplificados (ITS2, COI y 16S) utilizando protocolos de PCRs previamente descriptos. Las secuencias obtenidas se utilizaron para estudios de homología y construcción de árboles filogenéticos por medio del método de máxima verosimilitud. Por medio de la secuenciación se pudo confirmar que los dos aislamientos corresponden a Galba neotropica. Los estudios filogenéticos colocan ambos aislamientos dentro del grupo monofilético de $G$. neotropica junto a otros encontrados en distintas regiones de Sudamérica. Hasta lo que sabemos, el presente, es el primer registro de G. neotropica en Uruguay, además de comprobarse su capacidad para actuar como hospedero intermediario de Fasciola hepatica en condiciones de campo. Se sugieren futuros estudios para determinar la distribución y el rol de cada especie de limneido en la transmisión de $F$. hepatica.

Key words: Galba neotropica; Uruguay; molecular characterization

Palabras clave: Galba neotropica; Uruguay; caracterización molecular

\section{Introduction}

Fresh water gastropods of the family Lymnaeidae draw attention due to their role as intermediate hosts of several trematodes of public health and veterinary medicine concern. Particularly, from the zoonotic point of view, Fasciola hepatica, perhaps, is one of the most relevant parasites worldwide (Bargues and MasComa 2005; Correa et al., 2010). The adult fluke parasitizes the liver of a large variety of mammals including humans and it is a significant economic burden for livestock farmers. On the other hand, the larval stages develop inside lymnaeid snails until the cercariae leave them and encyst in the nearby 
vegetation turning into the infective forms (metacercariae). It is worth mentioning that not all the lymnaeid species have the same competence degree for harboring $F$. hepatica larval stages and the occurrence and distribution of fasciolosis is strictly dependent of the presence of a suitable lymnaeid species. Therefore, the correct characterization of lymnaeid species is of paramount importance for fasciolosis control campaigns.

Lymnaeids are cosmopolitan gastropods that inhabit aquatic and semiaquatic environments. For instance, Galba truncatula (= Lymnaea truncatula), the main intermediate host of $F$. hepatica in Europe, has been also found in distant locations such as the Bolivian Altiplano (Mas-Coma et al., 2001). Moreover, other lymnaeids such as Galba viatrix and Galba neotropica seem to have also a high adaptive behavior, as they were found in diverse environments in Argentina and Chile (Kleiman et al. 2007; Mera y Sierra et al. 2009; Artigas et al. 2011; Standley et al. 2013; Pujadas et al. 2015). In South America, the most important lymnaeid species involved in the life cycle of $F$. hepatica seemed to be Pseudosuccinea columella, G. truncatula, G. viatrix, Galba cubensis and G. neotropica (Bargues et al., 2007; Artigas et al., 2011). Traditionally, it was believed that only two species of lymnaeids occurred in Uruguay; the amphibious G. viatrix (= Lymnaea viatrix) and the aquatic $P$. columella. The species identification relied exclusively on morphological features (Doello Jurado 1917; Heinzen et al., 1994). However, in recent years, a molecular approach allowed the characterization of a third species, $G$. cubensis (= Lymnaea cubensis) from an isolate found in Paysandú (Correa et al., 2010).

The Lymnaeidae family taxonomy is in a constant debate. Morphological features vary among members of the same species, and sometimes, within the same population. This phenotypic plasticity is common and is determined mostly by developmental and environmental factors (Wullschleger and Jokela 2002). Particularly, within the Galba/Fossaria group, the socalled neotropical lymnaeid complex (G. neotropica, $G$. cubensis, $G$. viatrix) are phenotypically indistinguishable (Correa et al., 2011). Nevertheless, molecular markers such as cytochrome oxidase subunit 1 gene (COI), the $16 \mathrm{~S}$ ribosomal RNA gene and the internal transcribed spacer 2 gene (ITS2) proved to be very useful for species characterization among lymnaeids (Bargues et al., 2007; Artigas et al., 2011).

The aim of this study was to molecularly characterize different lymnaeid populations from the northern region of Uruguay and to report for the first time the detection of two populations of $G$. neotropica. In addition, to confirm this species as a competent intermediate host of $F$. hepatica under natural conditions.

\section{Materials and Methods}

\author{
Study area and lymnaeid collection
}

Lymnaeid snails were collected in farms located in Cuchilla de Peralta $\left(32^{\circ} 27^{\prime} \mathrm{S}, 56^{\circ} 17^{\prime} \mathrm{W}\right)$, and Paraje “Parada Daymán" (31 $\left.29^{\prime} \mathrm{S}, 57^{\circ} 52^{\prime} \mathrm{W}\right)$, Departments of Tacuarembó and Paysandú, respectively. Both Departments are located in the northern region of Uruguay. These two farms were selected due to their previous record of fasciolosis. At the Cuchilla de Peralta farm the collection was performed monthly during a 4month period (February-April 2015), while at Paraje "Parada Daymán" all the lymnaeids were obtained in only one collection (November 2015). All the snails were collected manually, kept alive and transported in water from their habitat to the laboratory.

\section{Conchological and parasitological analyses}

At the Departamento de Parasitología Veterinaria in Montevideo the lymnaeids were divided in two fractions; one fraction was used for conchological identification and searching of immature stages of $F$. hepatica, while the other fraction was sent to the Laboratorio de Vectores y enfermedades transmitidas in Salto for molecular analysis. For the parasitological examination, each lymnaeid was crashed between two slides and observed under the stereoscopic microscope.

\section{Molecular approach}

Upon arrival to the Laboratorio de Vectores $y$ enfermedades transmitidas, the specimens were placed in $1.5 \mathrm{ml}$ Eppendorf tubes and stored at $-20^{\circ} \mathrm{C}$ until use. Genomic DNA was extracted from the foot of each lymnaeid individually using the PureLink ${ }^{\mathrm{TM}}$ Genomic DNA kit (Invitrogen, Germany) following the tissue protocol described by the manufacturer. Three separated PCRs were carried out for the amplification of fragments of COI, 16S and ITS2 using primers and cycling conditions previously described (Folmer et al., 1994; Correa et al., 2010). The amplicons were visualized on $1.5 \%$ agarose gel containing $1: 2.5 \times 10^{-4}$ GoodViewTM (SBS Gentech, China) under UV light. The amplicons of three specimens of each population (Paysandú and Tacuarembó) were directly sequenced after purification using the PureLink ${ }^{\text {TM }}$ Quick PCR purification kit (Invitrogen, Germany). Sequencing was performed by Macrogen DNA Sequencing Service, South Korea. The sequences obtained were compared with entries in the GenBank nucleotide database, using BLASTN program (www.blast.ncbi.nlm.nih.gov). Sequences were aligned using CLUSTAL-W on MEGA 5.2 (Tamura et al., 2011) and, when needed, minor corrections were carried out manually. The phylogenetic relationships between our isolates and the species related were performed by the construction of maximum-likelihood (ML) trees using MEGA 5.2. The trees based on ITS2, COI and $16 \mathrm{~S}$ 
partial sequences were generated with the GTR model by using a discrete gamma-distribution $(+G)$. Node support was determined by bootstrapping with 1000 replicates in all cases.

\section{Results}

\section{Conchological and parasitological analyses}

Conchological analyses defined all lymnaeids $(n=246)$ as G. viatrix. Only two of the lymnaeids (collected in May at the Tacuarembó farm) presented larval stages of $F$. hepatica. The larval stages found in the snails were cercariae and rediae (Fig. $1 \mathrm{~A}$ and $\mathrm{B}$, respectively). The cercariae and rediae presented a morphology matching that of $F$. hepatica larval stages, as described previously (Thomas 1883; Dawes 1946; Olsen 1977). The distome gymnocephalus cercariae had no eyes but presented several cytogenus gland cells with dense dark granular content. These dark granules make the internal organs impossible to visualize. Moreover, the unforked tail's length was twice the size of the body. Rediae presented a prominent collar and a couple of parapodia near to the posterior end. Other three snails were also infected with cercariae and metacercariae of anunidentified trematode of the family Cyclocoelidae.
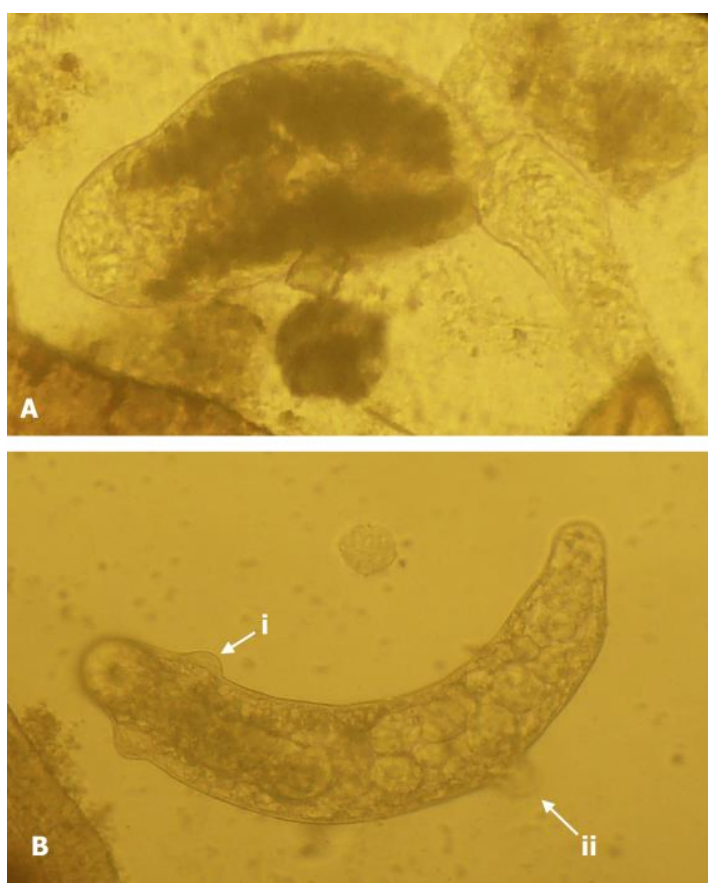

Figure 1. Fasciola hepatica larval stages found in two Galba neotropica specimens. A, immature cercaria and $\mathbf{B}$, redia showing parapodium (i) and collar (ii).

\section{Molecular approach}

Sequences obtained for each gene and isolate were registered in GenBank (16S: KX712144, KX756652; COI: KX781342, KX781341; ITS2: KX781343, KX781344). Both isolates showed $100 \%$ (COI DNA sequence) and 99\% (ITS2 DNA sequence) homology with registered sequences of $G$. neotropica. Meanwhile, the alignment of $16 \mathrm{~S}$ gene partial sequences evidenced a 2 base pair difference in all Tacuarembó isolates when comparing them with the Paysandú isolate and with reported sequences of $G$. neotropica. A transition ( $A$ to $G$ ) and a transversion ( $A$ to $C$ ) occurred on positions 276 and 301 , respectively. This difference was present in both forward and reverse sequences of all the Tacuarembó specimens. Therefore, $16 \mathrm{~S}$ gene sequences of Tacuarembó and Paysandú isolates were $99 \%$ and $100 \%$ homologous to $G$. neotropica, respectively. The phylogenetic analyses carried out with the ITS2 DNA region clustered both isolates among the mono-phyletic group of G. neotropica (Fig. 2). The tree inferred with COI also placed our isolated among the $G$. neotropica group but showed a closer relationship with $G$. cubensis than with $G$. viatrix (Fig. $3 \mathrm{~A}$ ). On the other hand, the $16 \mathrm{~S}$ tree placed the Tacuarembó isolate with G. cubensis registered in Cuba and both as sister species with the Paysandú isolate and $G$. neotropica from Argentina and Peru (Fig. 3B).

\section{Discussion}

Morphological features such as shells and internal reproductive organs have been used traditionally to identify and differentiate genera and species among gastropods. However, the plasticity of these features among the Galba/Fossaria group make them insufficient for achieving an identification up to species level and thus, molecular markers (mitochondrial and nuclear) have gained a key role on species characterization (Bargues et al., 2007; Standley et al., 2013). The morphological similarities between G. viatrix and G. neotropica were described in previous reports and the evidence of hybridization between them have been also found, making even more difficult the differentiation (Standley et al., 2013). For instance, our conchological findings suggested that all the specimens studied were G. viatrix. However, the molecular approach revealed that these specimens were, in fact, G. neotropica.

The ML tree constructed with ITS2 gene, placed both Uruguayan isolates among the monophyletic group of $G$. neotropica specimens of other South America regions and separated from the other Neotropical lymnaeids (G. viatrix and $G$. cubensis) (Fig. 2). The topology ITS2 tree was in concordance with the previous reports carried out by Artigas et al., 2011. On 
the other hand, the mitochondrial genes ( $\mathrm{COI}$ and $16 \mathrm{~S}$ ) showed a less clear species differentiation (Fig 3). Among these markers, ITS2 proved to be useful for phylogenetic analyses due to its relative fast evolution rate comparing with the mitochondrial genes (16S, COI). Nevertheless, $\mathrm{COI}$ gene had also proved its valuable use as barcoding marker (Standley et al. 2013).

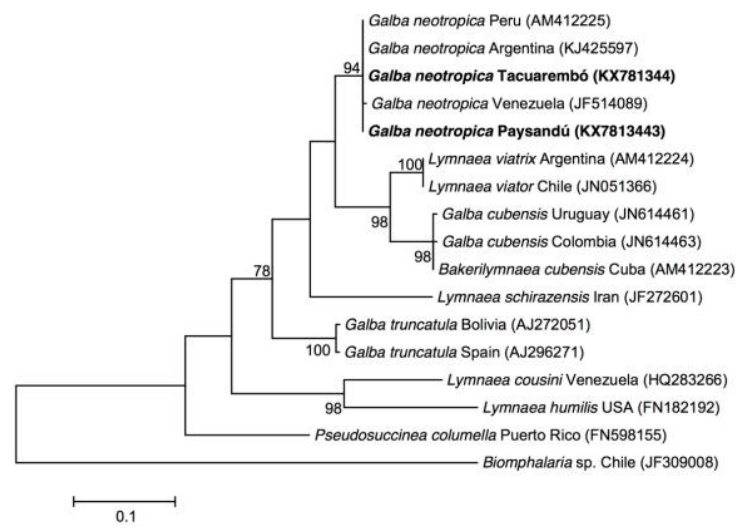

Figure 2. Phylogenetic tree of the nuclear gene ITS2. The tree was constructed using maximum likelihood model (GTR + G) with a bootstrap node support of 1000 replicates. Accession numbers of each species were added in brackets. Biomphalaria sp. was included as outgroup.

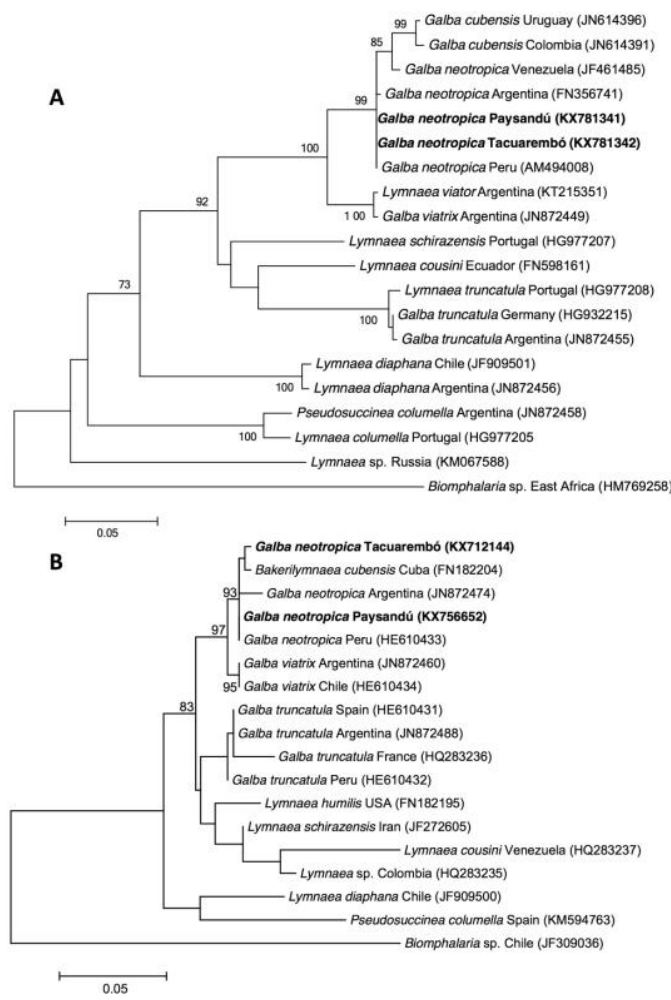

Figure 3. Phylogenetic trees of the mitochondrial $\mathrm{COI}$ (A) and $16 \mathrm{~S}$ (B) genes. The trees were constructed using maximum likelihood model (GTR $+G$ ) with a bootstrap node support of 1000 replicates. Accession numbers of each species were added in brackets. Biomphalaria sp. was included as outgroup.

Our findings constitute the first record of $G$. neotropica in Uruguay and added the third Neotropical lymnaeid species to the Uruguayan list (G. viatrix and G. cubensis were previously described by Doello Jurado 1917 and Correa et al., 2011). We are aware that the number of specimens molecularly analyzed ( 3 per isolate) was very small. Therefore, we cannot rule out the possibility that other Galba species could be present at the collection sites.

Galba neotropica had been confirmed as competent intermediate host of $F$. hepatica in the past (Mera y Sierra et al., 2009; Sanabria et al., 2012). Two snails collected in Tacuarembó during May 2015 harbored rediae and cercariae. The distinct morphological features and the record of endemic fasciolosis in the collection place strongly suggest that both larval stages were $F$. hepatica. This finding confirmed that, in natural conditions, $F$. hepatica miracidia can penetrate and further develop in G. neotropica. The detection of a new lymnaeid species emphasized the urge of further studies to determine the distribution as well as to define the relevance of each lymnaeid species on the transmission of $F$. hepatica in Uruguay.

\section{References}

Artigas P, Bargues MD, Mera y Sierra R, Agramunt VH, MasComa S. 2011. Characterisation of fascioliasis lymnaeid intermediate hosts from Chile by DNA sequencing, with emphasis on Lymnaea viator and Galba truncatula. Acta Trop. 120: 245-257.

Bargues MD, Mas-Coma S. 2005. Reviewing lymnaeid vectors of fascioliasis by ribosomal DNA sequence analyses. J. Helminthol. 79: 257-267.

Bargues MD, Artigas P, Mera y Sierra RL, Pointier JP, MasComa S. 2007. Characterisation of Lymnaea cubensis, $L$. viatrix and $L$. neotropica $\mathrm{n}$. sp., the main vectors of Fasciola hepatica in Latin America, by analysis of their ribosomal and mitochondrial DNA. Ann. Trop. Med. Parasitol. 101: 621-641.

Correa AC, Escobar JS, Durand P, Renaud F, David P, Jarne P, Pointier J-P, Hurtrez-Boussès $S$. 2010. Bridging gaps in the molecular phylogeny of the Lymnaeidae (Gastropoda: Pulmonata), vectors of Fascioliasis. BMC Evol. Biol. 10: 381.

Correa AC, Escobar JS, Noya O, Velásquez LE, GonzálezRamírez C. 2011. Morphological and molecular characterization of Neotropic Lymnaeidae (Gastropoda: Lymnaeoidea), vectors of fasciolosis. Infect. Genet. Evol. 11: 1978-1988.

Dawes B. 1946. The trematoda: with special reference to British and other European forms. Cambridge Univ. Press. 644 pp.

Doello Jurado M. 1917. Lymnaea viatrix en el Río de la Plata. Physis 3: 443. 
Folmer O, Black M, HoehW, Lutz R, Vrijenhoek R. 1994. DNA primers for amplification of mitochondrial cytochrome C oxidase subunit I from diverse metazoan invertebrates. Mol. Mar. Biol. Biotechnol. 3: 294-299.

Heinzen T, Castro O, Pepe C, Ibarburu A. 1994. Lymnaea columella como hospedero intermediario de Fasciola hepática en Uruguay, in: XXII Jornadas Uruguayas de Buiatría. Centro Médico Veterinario de Paysandú, Paysandú, Uruguay.

Kleiman F, Pietrokovsky S, Prepelitchi L, Carbajo AE, Wisnivesky-Colli C. 2007. Dynamics of Fasciola hepatica transmission in the Andean Patagonian valleys, Argentina. Vet Parasitol. 145: 274-286.

Mas-Coma S, Funatsu IR, Bargues MD. 2001. Fasciola hepatica and lymnaeid snails occurring at very high altitude in South America. Parasitology 123 Suppl: S115-S127.

Mera y Sierra R, Artigas $P$, Cuervo $P$, Deis E, Sidoti L, MasComa S, Bargues MD. 2009. Fascioliasis transmission by Lymnaea neotropica confirmed by nuclear rDNA and mtDNA sequencing in Argentina. Vet. Parasitol. 166: 73-79.

Olsen OW. 1977. Parasitología animal: Platelmintos, acantocefalos y nemaatelmintos. II. Aedos. Barcelona. $719 \mathrm{pp}$.

Pujadas JM, Farber M, Pointier J-P, Giudici C, Wisnivesky C, Prepelitchi L. 2015. New record for Galba neotropica (d'Orbigny, 1835) in Argentina, with a detailed analysis of its morphology and molecular characteristics. Molluscan Res. 35: 153-160.

Sanabria R, Mouzet $R$, Courtioux $B$, Vignoles $P$, Rondelaud $D$, Dreyfuss G, Cabaret J, Romero J. 2012. Intermediate snail hosts of French Fasciola hepatica: Lymnaea neotropica and Lymnaea viatrix are better hosts than local Galba truncatula. Parasitol. Res. 111: 2011-2016.

Standley CJ, Prepelitchi L, Pietrokovsky SM, Issia L, Stothard JR, Wisnivesky-Colli C. 2013. Molecular characterization of cryptic and sympatric lymnaeid species from the Galba/Fossaria group in Mendoza Province, Northern Patagonia, Argentina. Parasit. Vectors 6: 304.

Tamura K, Peterson D, Peterson N, Stecher G, Nei M, Kumar S. 2011. MEGA5: Molecular Evolutionary Genetics Analysis Using Maximum Likelihood, Evolutionary Distance, and Maximum Parsimony Methods. Mol. Biol. Evol. 28: 2731-2739.

Thomas AP. 1883. The Life History of the Liver-Fluke (Fasciola hepatica). Q. J. Microsc. Sci. 23: 99-133.

Wullschleger EB, Jokela J. 2002. Morphological plasticity and divergence in life-history traits between two closely related freshwater snails, Lymnaea ovata and Lymnaea peregra. J. Molluscan Stud. 68: 1-5. 